\title{
EXAMINATION OF THE TRANSITION TO POSTMODERNISM IN AIR TRAFFIC CONTROL SERVICES FROM THE PERSPECTIVE OF CONTROLLERS
}

\author{
Cankut AYDIN ${ }^{1}$ \\ Southern University Institute of Management Business and Law, \\ Rostow-on-Don Russia \\ Ertan ÇINAR ${ }^{2}$ \\ Eskişehir Technical University, Turkey
}

\section{Introduction}

With the increase in air vehicles the fact that air transportation has started to be preferred as a safe and fast means of transportation has also caused an increase in air traffic. In this context, in light of the developments in technology, the density of air traffic is increasing day by day. In addition, it can be said that the reason for the rapid increase in air traffic is the liberalization process that started in 1978 in the United States of America. Considering the last 40 years, it is observed that significant progress has been made in the development of civil aviation. It was seen that the Federal Aviation Law in 1938 brought important economic regulations for the USA, the world's largest air transport market, and the Airline Deregulation Act, which was implemented in 1978, made the air transport development process more effective (Button, 2019).

1 cankut.aydin@ @uimbl.ru

\begin{tabular}{|c|c|c|}
\hline (cc) & 58 & $\begin{array}{r}\text { (c) } 2021 \text { The Authors. This is an open-access article } \\
\text { distributed under the terms of the Creative Commons } \\
\text { Attribution License. }\end{array}$ \\
\hline
\end{tabular}


The aviation sector, which could not reach the desired level until the liberalization period, has achieved a very rapid growth especially with the developments experienced since this period. With the liberal economy providing the necessary infrastructure to all stakeholders operating in the aviation sector in recent years, the aviation sector has also started to play an important role in the development of countries (Dursun, 2021; Efendigil \& Eminler, 2017). In addition, it has been observed that air traffic has doubled every 15 years since 1978 .

Air transport has a vital role in sustaining economic and social development. In this context, the air transport sector provides employment to 58.1 million people in the world directly and indirectly. Moreover, the contribution of countries to the gross domestic product (GDP) is 2.4 trillion dollars. In air transportation, more than 3 billion passengers and 6.4 trillion dollars worth of freight are transported annually (ICAO, 2016a). The aviation sector is approximately 4.4 times more efficient than other sectors in the economy. Considering the scope of the industry, it is known that 1303 airlines operate 45,091 points between 3759 airports in the airspace managed by 170 air navigation service providers. About $57 \%$ of the world's tourists travel using air transport. In addition, it is predicted that the projected growth in air transport will employ approximately 97.8 million people in 2036 and support the economic development of 5.7 trillion dollars (Dursun, Aydın, Çınar, and Sertkaya, 2021; Higgoda and Madurapperuma, 2019).

In the literature review, it is seen that the authors, who exhibit a post-modern approach in their works, work in many different fields such as philosophy, art, literature, architecture, physics, mathematics, sociology, economy, business, and communication. The concept of post-modernism, which has predominantly taken place in the field of management organization, has been applied in a different area with this study.

Lacan, (2019) argues why today's business world and managers, in general, should revise themselves from a postmodern perspective. It emphasizes the need to move from production and individual performance-oriented working model to an axis that emphasizes human relations and creativity (postmodernism).

Dragomir, (2019), the male-oriented work environment stemming from modernism has a significant effect on women's preference for the maritime sector in today's post-modern understanding. Gender equality in maritime businesses is still considered taboo.

In the study it is emphasized that if strategies are developed to increase the motivation of women, their career goals can be turned into the field of maritime. Öztürk, (2019) examined the historical process and conceptual framework of postmodernism and examined its effect on human behavior in the business in the 
process. As a result, he stated that people of postmodernism are consumption and competition-oriented individuals with high job motivation and knowledge management skills, and low interest in social events. Eraslan, (2018) examined the effects of the concept of postmodernism on business management. In this context, he stated that due to the increase in digitalization that developed with the postmodernism period, the decrease in the interest in unskilled employees led to an increase in the unemployment rate.

Tahtalığlu, (2018) stated that the post-modern management approach could not achieve the desired effect on public administration. The reason for this is that the effects of features such as central management, objectivity and hierarchy, which are the principles of the modern management approach, cannot be broken.

Demirel (2014) stated that postmodernism defends principles such as horizontal organization, openness and participation in public administration by criticizing modern and bureaucratic management styles. He stated that the postmodern management approach aims to solve the deficiencies of traditional management approaches and restructures the management.

Özdemir, (2014), in his study aims to determine the effects of the postmodern management approach of the developments occurring in the education system of our country, the post-modern management understanding on education system; It has been emphasized that it has effects with features such as a decrease in the hierarchy, adoption of decentralized management, transfer of authority to lower levels, and digital transformation in educational technologies.

Kemp, (2013) focuses on Taylor's journey from modernism to postmodernism. Emphasizing that sharing knowledge through teamwork and thus eliminating the hierarchical structure in the modern sense will increase industrial efficiency and production quality; scientific management is explained by four important principles:

- Development of real science,

- Scientific selection of employees,

- Scientific education and development,

-Friendly, sincere cooperation between employees and management.

The subject of this study has been determined as "Examining the Transition to Postmodernism in Air Traffic Control Services from the Perspective of Controllers". In this context, it is the measurement of the extent to which the employees in this field are exposed to the effects of postmodernism, especially in air transportation and air traffic control, and to what extent they understand the effects of this change in 
the organization they work in. As a result of the measurement, with the new concepts proposed for the improvement of the management processes, the behavior of the employees and the business; It is aimed at increasing the efficiency and productivity.

\section{Important developments enabling the transition to the postmodern structure}

The most important developments in the transition to the postmodern structure are examined under three headings: developments in information and communication technology, the spread of this development to the whole world with globalization, and the human factor that produces information (Ulutaş, 2018).

a-Information and Communication Technology: Constantly developing information also constantly changes the business processes of businesses (Ulutaş, 2018). Developments in information and communication technology (ICT) take place and are used in people's lives from an early age. All communities endeavor to use ICT to produce technologies and make the technologies a part of their lives in order to become an information society (Akgün \& Yaşar, 2016). From vertical organization to subcontractor; from economy of size to flexible small structures; from high hierarchical organization to lean organization; from bureaucratic personality to entrepreneurial personality; the transition process from increasing the market share to creating a new market" has occurred (Koçel, 2001, cited by Ulutaş, 2018).

B-Gobalization: Globalization has become a word used to express the developments in all fields from information technologies to aviation, from economy to politics. Especially since the 1990s, the concept of "globalization", which has affected all areas of life, has become the most common trend in the world. Therefore, the concept of globalization affects all actors in the sectors with its advantages and disadvantages (Zerenler et al., 2014). In the post-modern period, especially with the development in communication technologies, the world has become a single market. Therefore, the dependencies of the sectors on each other have increased. In other nations it is so possible to feel the influence of the political or economic crises anywhere in the globe (Ulutaş, 2018).

\section{2- Increase in Human factor importance}

Since the first successful flight recorded in history in 1903, the costs and number of deaths in the aviation field have increased day by day. For this reason, efforts to reduce accident rates in the field of aviation have gained importance today (Metin, 2014). In the post-modern period, phenomena such as bringing people's personality to the forefront, benefiting from human rights and people's creativity have become very important. In this period, people are not at the disposal of 
machines, but machines are at the disposal of people. In this context, the human factor is not a part responsible for a certain part of the production phase, but a part that plans, fulfills and finalizes the production from the beginning to the end (Ulutaş, 2018).

The most important suggestion made for the detection of human errors in aviation is the "Swiss Cheese" (Figure 1) model created by James Reason in 1990.



Figure 1. Swiss cheese Model (Metin, 2014).

According to this model, human errors are classified into four stages. The first stage after the accident is the "unsafe acts" stage. This stage is called the active error period and is the part where human error is most frequently emphasized in accident investigations. The underlying causes that emerge after a certain period of time include the stages of ground-forming factors, insecure management, and organizational factors, called "latent factors".

\section{3- Problem and hypotheses of the research}

Civil aviation activities in the world are enhancing rapidly with globalization and other factors, and air traffic is increasing rapidly. Therefore, air traffic controllers are critical in managing the increasing air traffic. In this context, the problem of the research is "Can the management processes be improved in the context of the effectiveness and efficiency, employee behavior, safety and work motivation of the revisions and improvements in air traffic control services on air traffic controllers with the post-modern management approach?" in the form. 
- In this context, the hypotheses of the research are explained in Table 1.

\section{Table 1. Research Hypotheses}

\begin{tabular}{|l|l|}
\hline \multicolumn{2}{|c|}{ Research Hypotheses } \\
\hline H1 & $\begin{array}{l}\text { Postmodernization of Existing Management Processes increases the } \\
\text { effectiveness and efficiency of the air traffic control service. }\end{array}$ \\
\hline H2 & $\begin{array}{l}\text { Postmodernization of existing Management Processes increases the } \\
\text { safety of the air traffic control service. }\end{array}$ \\
\hline H3 & $\begin{array}{l}\text { Postmodernization of Existing Management Processes increases the } \\
\text { work motivation of controllers. }\end{array}$ \\
\hline H4 & $\begin{array}{l}\text { Postmodernization of Existing Management Processes strengthens the } \\
\text { employee relations (behaviors) of controllers. }\end{array}$ \\
\hline
\end{tabular}

\section{Method}

The population of the research consists of licensed air traffic controllers in Turkey. As a result of the information received from the officials of the General Directorate of Civil Aviation, there are 1,759 air traffic controllers working actively as of 2019. Almost all of the licensed air traffic controllers in our country are employed by the General Directorate of State Airports Authority (DHMI), a stateowned enterprise under the responsibility of the Ministry of Transport and Infrastructure. The Turkish Air Traffic Controllers Association assumed the duty of the non-governmental organization in which the aforesaid task group was professionally organized and supported administratively by the General Directorate of State Airports Authority and allowed to perform its activities within the institution. Active duty air traffic controllers maintain their professional solidarity and association with the aforementioned non-governmental organization. Therefore, although the population and sample of this survey are composed of association members; the survey was completed by applying it to 225 air traffic controllers who are members of the aforementioned association.

The limitations of the research are stated below:

- Due to the COVID-19 outbreak, the survey application was carried out only over the internet.

- It is assumed that the determined sample group represents the whole universe.

- The dimension of aviation security exercised by law enforcement within the scope of post-modern management has been excluded.

- Findings determined within the scope of the research are limited to the attitudes of the controllers at the time of the research. 


\section{1- Collecting survey data}

Within the scope of the research, a questionnaire consisting of four parts has been applied. In the first part of the questionnaire, 6 multiple-choice questions were directed to determine demographic variables such as age, marital status, professional experience, gender and educational status of the participants.

In the second part of the questionnaire, 8 statements are directed to determine the characteristics of the task carried out in the context of the traditional management approach (classical and neo-classical). In the third part of the questionnaire, 10 statements are directed towards the measurement of the relationship and communication network (behavioral) within the organization. In the fourth part of the questionnaire, 16 statements based on information technologies, human resources, and globalization are directed to determine the adaptation of the organization to post-modern management. The second, third and fourth parts of the questionnaire included closed-ended questions prepared according to a 5-point Likert scale. In these sections, the answers about each of the statements directed to the survey participants; were asked to state as "1. Absolutely Disagree, 2. I Disagree, 3. I Am Indecisive, 4. I Agree, 5. I Absolutely Agree".

\section{Findings}

The analysis process of the research data has been examined under eight headings. Firstly, distributions and graphs of demographic characteristics are given. In the second stage, the results of the pilot study of the post-modernization scale, which was desired to be developed as a measurement tool, were evaluated. In the third stage, exploratory and confirmatory factor analysis was applied for construct validity. In the fourth step, the test-retest reliability of the scale and its internal consistency with the Cronbach alpha coefficient were examined. In the fifth stage, demographic characteristics were compared according to the mean scores of the subdimensions of the post-modernization scale. In the sixth stage, the relationships between the sub-dimensions were analyzed by correlation analysis, and finally, the structural equation model created was tested.

\section{1- Distribution of demographic characteristics}

The demographic characteristics of the employees $(n=225)$ participating in the study from the air traffic control area are presented in Table 2 with their frequency and percentage values. When the table is examined; While $72.9 \%(\mathrm{n}=$ 164) of those working in the field of air traffic control are men, $27.1 \%(n=61)$ are women. 
While $27.6 \%(n=62)$ of those working in the field of air traffic control are married, $70.7 \%(\mathrm{n}=159)$ are single and $1.8 \%$ are in the other marital status group. $0.4 \%(\mathrm{n}=1)$ of those working in the field of air traffic control are high school graduates, while $3.1 \%(\mathrm{n}=7)$ are associate degree graduates, $52.7 \%(\mathrm{n}=118)$ are undergraduate, $39 \% .3(n=88)$ of them are postgraduate graduates and $4.5 \%(n=10)$ of them are doctoral graduates. This shows that almost all of the air traffic controllers are graduates of higher education.

While $10.7 \%(\mathrm{n}=24)$ of those working in the field of air traffic control are in the $18-25$ age range, $35.6 \%(\mathrm{n}=80)$ in the $26-35$ age range, $51.1 \%(\mathrm{n}=115)$ In the age range of $36-50,2.7 \%(n=6)$ were 51 years old and above. This shows that the air traffic controllers participating in our survey are mostly in the young age group; For this age group, it is possible to predict the age group that is open to learning and change towards postmodernism.

While $10.2 \%(n=23)$ of those working in the field of air traffic control have a total working time of 1 month-1 year, $15.1 \%(\mathrm{n}=34) 2-4$ years, $49.3 \%(\mathrm{n}=111)$ are 5-10 years, $25.3 \%(n=57)$ of them are 11 years and over. While $12.4 \%(n=28)$ of those working in the field of air traffic control are managers in the workplace they work, $87.6 \%(n=197)$ are not managers.

Table 2. Distributions of Demographic Characteristics

\begin{tabular}{lll}
\hline & $\begin{array}{l}\text { Kişi Sayısı } \\
(\mathrm{n}=225)\end{array}$ & $\begin{array}{l}\text { Yüzde } \\
(\%)\end{array}$ \\
\hline Gender & 164 & 72,9 \\
Male & 61 & 27,1 \\
Female & & \\
\hline Marital Status & 62 & 27,6 \\
Married & 159 & 70,7 \\
Single & 4 & 1,8 \\
Other & & \\
\hline Education Status $(\mathrm{n}=224)$ & 1 & 0,4 \\
High School & 7 & 3,1 \\
Undergraduate & 118 & 52,7 \\
Bachelor & 88 & 39,3 \\
Master Degree & 10 & 4,5 \\
Doctoral & & \\
\hline Age Group & 24 & 10,7 \\
18-25 years & 80 & 35,6 \\
26-35 years & 115 & 51,1 \\
36-50 years & 6 & 2,7 \\
51 years and above & & \\
\hline
\end{tabular}




\begin{tabular}{lll}
\hline & $\begin{array}{l}\text { Kişi Sayısı } \\
(\mathrm{n}=225)\end{array}$ & $\begin{array}{l}\text { Yüzde } \\
(\%)\end{array}$ \\
\hline Your total working time within the scope of aviation & & \\
activities & 23 & 10,2 \\
1 month -1 year & 34 & 15,1 \\
2-4 years & 111 & 49,3 \\
5-10 years & 57 & 25,3 \\
11 years and above & & \\
\hline Are you a manager at your workplace? & 28 & 12,4 \\
I am a manager & 197 & 87,6 \\
I am not a manager & & \\
\hline
\end{tabular}

\section{1- Pilot work}

In order to evaluate the intelligibility of the scale, a pilot study was conducted on a group of 30 people who had the characteristics of the sample group and were not included in the research. After the pilot application, it was seen that the Postmodernization Scale of the Current Management processes was understandable and the scale took its final form with 33 items.

\section{2- Structure validity}

In order to determine the construct validity within the scale, factor analysis is used, which allows the variables to be collected in certain groups. It is the reduction of data in order to facilitate the interpretation and comprehensibility of the relationships between factor analysis and data (Çokluk, Şekercioğlu, \& Büyüköztürk, 2012).

\section{3- Exploratory factor analysis}

The results of the exploratory factor analysis of the post-modernization scale of existing management processes are presented in Table 3.

Table 3. KMO Value of Post-Modernization Scale of Existing Management Processes and Bartlett Sphericity Test Results

\begin{tabular}{lll}
\hline KaiserMeyerOlkin (KMO) & & 0,880 \\
\hline \multirow{3}{*}{ Bartlett Globalization Test } & Chi-Square & 4508,017 \\
\cline { 2 - 3 } & Df & 300 \\
\cline { 2 - 3 } & $\mathrm{P}$ & $\mathbf{0 , 0 0 0}$ \\
\hline
\end{tabular}

${ }^{*} p<0,001 \quad d f=$ Degress of Freedom $p=$ Significance Level

Looking at the results of Table 3, it is seen that the Kaiser Meyer Olkin (KMO) value is 0.880 . The KMO value, which can have a value between 0 and 1 , provides | www.ejsr.org 
a more reliable factor structure as it approaches 1 (Özdamar, 2017). According to this result, it was evaluated that the results to be found as a result of factor analysis in the study would be useful and usable. Since the $p<0.001$ value was determined according to the Barlett test result, it was determined that there was a significant relationship between the variables and it was appropriate to perform factor analysis on the data.

The Principal Components method to the Postmodernization Scale of the Current Management processes, which consists of 33 items, and the Varimax rotation method, which is a type of orthogonal rotation, was used. The scale consisting of 33 items was divided into 4 sub-dimensions as a result of the analysis items with a factor load of less than 0.300 and loaded on more than one factor were removed from the scale and reduced to 25 items.

Items extracted from the scale, factor loads of the scale articles and their explanatory ratios are presented in the Tables 4 and 5:

Table 4. Variance Explanation Table of the Postmodernization Scale of Existing Management Processes

\begin{tabular}{lllllll}
\hline & \multicolumn{2}{c}{ Beginning Egenvalues } & \multicolumn{3}{c}{ Total Factor Loads (Converted) } \\
\cline { 2 - 7 } & Total $\begin{array}{l}\text { Explained } \\
\text { Variance } \\
\%\end{array}$ & $\begin{array}{l}\text { Cumulative } \\
\%\end{array}$ & Total & $\begin{array}{l}\text { Explained Cumulative } \\
\text { Variance\% } \%\end{array}$ \\
\hline Factor 1 (IK) & 11,42 & 45,69 & 45,69 & 6,47 & 25,88 & 25,88 \\
\hline $\begin{array}{l}\text { Factor 2 } \\
\text { (IT/Global) }\end{array}$ & 1,97 & 7,88 & 53,57 & 4,10 & 16,41 & 42,30 \\
\hline Factor 3 (Duty) & 1,79 & 7,14 & 60,71 & 3,73 & 14,92 & 57,22 \\
\hline $\begin{array}{l}\text { Factor 4 } \\
\text { (Relationship) }\end{array}$ & 1,40 & 5,59 & 66,30 & 2,27 & 9,08 & $\mathbf{6 6 , 3 0}$ \\
\hline
\end{tabular}

When Table 4 is examined; factor 1 explained $25.88 \%$ of the total variance, factor 2 explained $16.41 \%$ of the total variance, factor 3 explained $14.92 \%$ of the total variance, and factor 4 explained $9.08 \%$ of the total variance. Together, the factors explain $66.30 \%$ of the total variance. 
Table 5. Factor Load Values Regarding the Articles of the Postmodernization Scale of Existing Management Processes

\begin{tabular}{|c|c|c|}
\hline Article & Expressions & $\begin{array}{l}\text { Factor Load } \\
\text { (Final } \\
\text { Form) }\end{array}$ \\
\hline \multicolumn{3}{|c|}{ Factor 1 Organization's Adaptation to Postmodernism (IK) } \\
\hline PM31 & $\begin{array}{l}\text { I am supported to make decisions on my own within the } \\
\text { organization. }\end{array}$ & 0,807 \\
\hline PM18 & We work in continuous solidarity with managers. & 0,800 \\
\hline PM33 & First of all, work is produced within the institution. & 0,787 \\
\hline PM8 & Correct and timely work in the institution is rewarded. & 0,777 \\
\hline PM7 & $\begin{array}{l}\text { There is a clear overlap between the roles in the organization I work } \\
\text { for and the people. }\end{array}$ & 0,742 \\
\hline PM30 & I am supported to make decisions on my own within the unit. & 0,730 \\
\hline PM13 & I get along well with everyone in the organization. & 0,683 \\
\hline PM17 & As a unit, we react quickly to external works. & 0,681 \\
\hline PM32 & First of all, work is observed in the unit. & 0,632 \\
\hline PM9 & $\begin{array}{l}\text { The superior-subordinate relationship is defined within the } \\
\text { institution. }\end{array}$ & 0,613 \\
\hline \multicolumn{3}{|c|}{ Factor 2 Organization's Adaptation to Postmodernism (IT/Global) } \\
\hline PM22 & I quickly adapt to computer operating system changes. & 0,832 \\
\hline PM21 & I quickly adapt to Internet-based applications. (ebys, kepvs) & 0,766 \\
\hline PM24 & Computer technologies are used extensively in in-house work. & 0,691 \\
\hline PM20 & I use the internet extensively while doing my job. & 0,674 \\
\hline PM19 & I use the computer extensively while doing my job. & 0,669 \\
\hline PM23 & Information technologies are used extensively in internal work. & 0,662 \\
\hline \multicolumn{3}{|c|}{ Factor 3 Evaluations of the Engagement (Duty) } \\
\hline PM2 & How to do my task is clearly explained to me. & 0,821 \\
\hline PM3 & I know to which units the unit I work for is responsible. & 0,755 \\
\hline PM1 & My job description is clear. & 0,682 \\
\hline PM5 & I do the tasks given in the unit as quickly as possible. & 0,641 \\
\hline PM25 & My unit works internationally. & 0,630 \\
\hline \multicolumn{3}{|c|}{$\begin{array}{l}\text { Factor } 4 \text { Relationship and Communication Network within the } \\
\text { Organization (Relationship) }\end{array}$} \\
\hline PM10 & There is grouping among the employees within the unit. & 0,843 \\
\hline PM14 & $\begin{array}{l}\text { Different tasks can be assigned by observing personal relationships } \\
\text { within the unit. }\end{array}$ & 0,612 \\
\hline PM11 & $\begin{array}{l}\text { There is a leader within the unit that is not determined by the } \\
\text { management. }\end{array}$ & 0,586 \\
\hline PM16 & I help my friends in addition to the tasks given in the unit. & 0,498 \\
\hline \multicolumn{3}{|c|}{ Articles Removed After Exploratory Factor Analysis } \\
\hline PM29 & \multicolumn{2}{|l|}{$\begin{array}{l}\text { I can behave comfortably (state, movement, address, demeanor) in inter-unit } \\
\text { relations. }\end{array}$} \\
\hline PM12 & \multicolumn{2}{|l|}{ I get along well with everyone in the unit. } \\
\hline PM28 & \multicolumn{2}{|l|}{ My organization responds quickly to international assignments. } \\
\hline
\end{tabular}




\begin{tabular}{|l|l|}
\hline PM27 & My unit responds quickly to international missions. \\
\hline PM6 & $\begin{array}{l}\text { All of the employees in the unit I work in have received appropriate training for } \\
\text { this unit. }\end{array}$ \\
\hline PM4 & The division of tasks within the unit has been clearly defined. \\
\hline PM15 & I can make my own decisions to speed up the processes in the given tasks. \\
\hline PM26 & My institution works internationally. \\
\hline
\end{tabular}

\subsubsection{Confirmatory factor analysis}

DFA analysis was performed to verify the postmodernization scale of current management processes, which were determined as 25 articles and 4 sub-dimensions with the exploratory factor analysis, and the scale was made compatible with the data. The measurement model established to verify the structure consisting of 25 articles and 4 sub-dimensions was analyzed with primary level CFA. As a result of the analysis, it was seen that the model did not fit sufficiently, so model improvement studies were carried out. In order to improve the model, the factor load values of the Articles were examined and 8 Articles with low contribution to the model were removed from the scale (PM7, PM9, PM10, PM13, PM18, PM20, PM23, PM32). The final form of the scale used is given in table 6. At the same time, chi-square decline values (M.I.) values were examined for possible changes to the model by examining the table of modification indexes. The highest "M.I" The model was carried out by linking the modification indicated by the value $(\mathrm{e} 7<->\mathrm{e} 8, \mathrm{e} 13<->\mathrm{e} 14$, e13<->e16) when conceptually appropriate. It was determined in table 7 that the measurement model was verified by looking at the fit index values of the model. The validated measurement model is presented in figure 2 .

Table 6. Articles of the postmodernization scale of the existing management processes used

\begin{tabular}{|l|l|}
\hline Article & Expressions \\
\hline Factor 1 Organization's Adaptation to Postmodernism (IK) \\
\hline PM31 & I am supported to make decisions on my own within the organization. \\
\hline PM33 & First of all, work is produced within the institution. \\
\hline PM8 & Correct and timely work in the institution is rewarded. \\
\hline PM30 & I am supported to make decisions on my own within the unit. \\
\hline PM17 & As a unit, we react quickly to external works. \\
\hline Factor 2 & Organization's Adaptation to Postmodernism (IT/Global) \\
\hline PM22 & I quickly adapt to computer operating system changes. \\
\hline PM21 & I quickly adapt to Internet-based applications. (ebys, kepvs) \\
\hline PM24 & Computer technologies are used extensively in in-house work. \\
\hline PM19 & I use the computer extensively while doing my job. \\
\hline Factor 3 Evaluations of the Engagement (Duty) \\
\hline PM2 & How to do my task is clearly explained to me. \\
\hline PM3 & I know to which units the unit I work for is responsible. \\
\hline PM1 & My job description is clear. \\
\hline
\end{tabular}

| www.ejsr.org 


\begin{tabular}{|l|l|}
\hline PM5 & I do the tasks given in the unit as quickly as possible. \\
\hline PM25 & My unit works internationally. \\
\hline $\begin{array}{l}\text { Factor } 4 \\
\text { Relationship and Communication Network within the Organization } \\
\text { Relationship) }\end{array}$ \\
\hline PM14 & $\begin{array}{l}\text { Different tasks can be assigned by observing personal relationships within the } \\
\text { unit. }\end{array}$ \\
\hline PM11 & There is a leader within the unit that is not determined by the management. \\
\hline PM16 & I help my friends in addition to the tasks given in the unit. \\
\hline
\end{tabular}

When the measurement model verified with 17 Articles and 4 sub-dimensions is examined in Figure 2, the standardized regression coefficients or factor loadings of the Articles that make up the model and the paths on the one-way arrows are indicated. As a result of the examination of the factor load of each item, a value below 0.3 was not determined. In this context; PM8 expression is the strongest indicator of F1 (IK) sub-dimension with a value of 0.93, PM22 expression is the strongest indicator of F2 (IT / Global) sub-dimension with a value of 0.77, PM2 expression is a value of 0.9 and F3 (Task) sub-dimension is the strongest indicator, and PM16 expression is the strongest indicator of the F4 (Relationship) subdimension with a value of 0.61

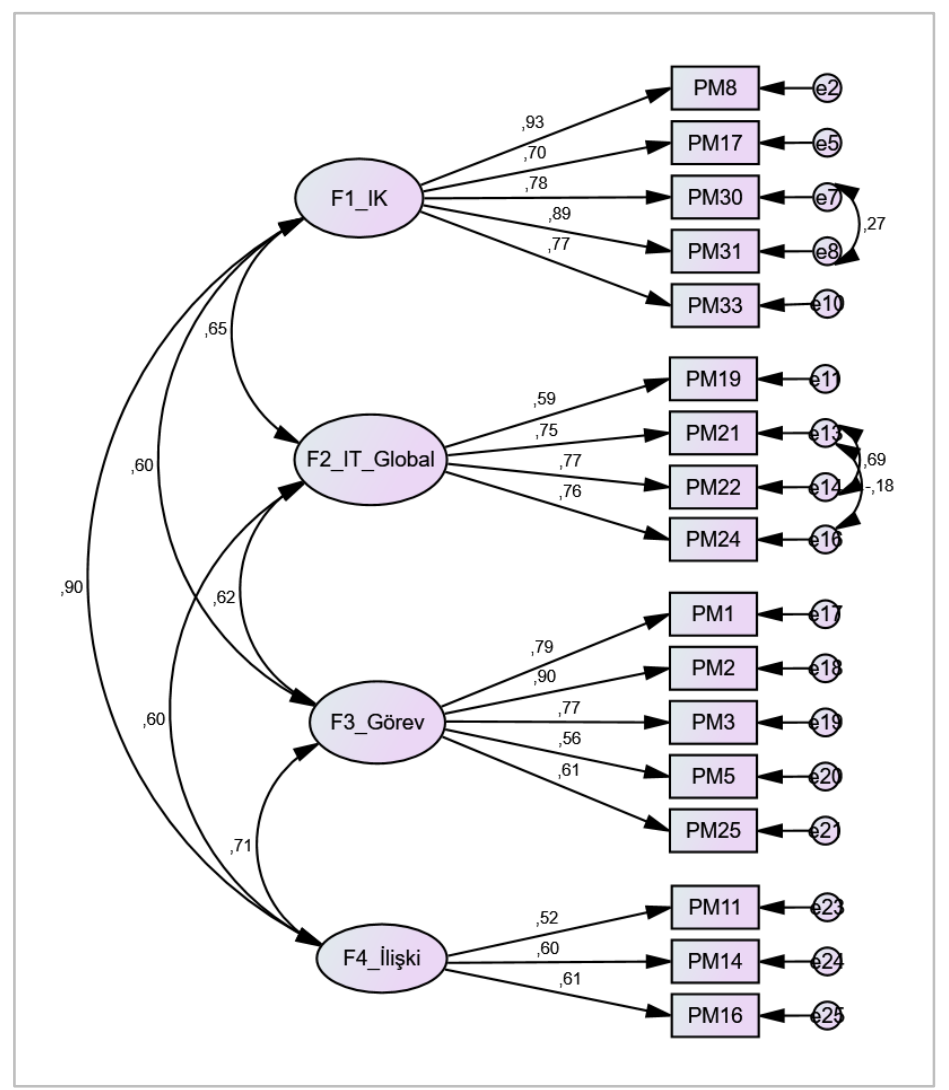

Figure 2. Measurement Model of Postmodernization Scale of Existing Management processes 


$$
\begin{gathered}
\text { F1_IK=IK (Job Motivation) } \\
\text { F2_IT_Global=IT/Global (Safety of Service) } \\
\text { F3_Duty=Duty (Service Productivity and Efficiency) } \\
\text { F4_Relationship = Relationship (Behavioral) }
\end{gathered}
$$

In the examination of the fit index values of the measurement model, it is recommended to use a large number of fit indices in determining the harmony between the theoretical model and the data, as they have strengths and weaknesses

\begin{tabular}{|c|c|c|c|c|}
\hline & $\begin{array}{l}\text { Adaptation } \\
\text { Index Values } \\
\text { of Model }\end{array}$ & $\begin{array}{l}\text { Good } \\
\text { Adaptation }\end{array}$ & $\begin{array}{l}\text { Acceptable } \\
\text { Adaptation }\end{array}$ & Adaptation \\
\hline$\chi^{2} / \mathbf{s d}$ & 2,357 & $\leq 3$ & $4-5$ & $\begin{array}{l}\text { Good } \\
\text { Adaptation }\end{array}$ \\
\hline GFI & $\mathbf{0 , 8 8 2}$ & $\geq 0,90$ & $(0,89-0,85)$ & $\begin{array}{l}\text { Acceptable } \\
\text { Adaptation }\end{array}$ \\
\hline AGFI & $\mathbf{0 , 8 5 5}$ & $\geq 0,90$ & $(0,89-0,85)$ & $\begin{array}{l}\text { Acceptable } \\
\text { Adaptation }\end{array}$ \\
\hline NFI & 0,902 & $\geq 0,95$ & $(0,94-0,90)$ & $\begin{array}{l}\text { Acceptable } \\
\text { Adaptation }\end{array}$ \\
\hline $\begin{array}{l}\text { NNFI } \\
\text { (TLI) }\end{array}$ & 0,919 & $\geq 0,95$ & $(0,94-0,90)$ & $\begin{array}{l}\text { Acceptable } \\
\text { Adaptation }\end{array}$ \\
\hline CFI & 0,934 & $\geq 0,95$ & $\geq 0,90$ & $\begin{array}{l}\text { Acceptable } \\
\text { Adaptation }\end{array}$ \\
\hline RMSEA & 0,078 & $\leq 0,05$ & $(0,06-0,08)$ & $\begin{array}{l}\text { Acceptable } \\
\text { Adaptation }\end{array}$ \\
\hline SRMR & 0,052 & $\leq 0,05$ & $(0,06-0,08)$ & $\begin{array}{l}\text { Good } \\
\text { Adaptation }\end{array}$ \\
\hline
\end{tabular}
between them (Büyüköztürk, et al.2004). In this context, fit index values used within the scope of the study are presented in Table 7.:

Table 7. Adaptation Index Values of Scale Model

The fit index values of the measurement model are given in Table 7 . When the fit index values obtained for the measurement model are examined, it can be said that $\chi^{2}$ sd and SRMR values have good fit values, and GFI, AGFI, CFI, NFI, NNFI (TLI) and RMSEA values have acceptable fit values. 


\subsubsection{Reliability analysis}

Reliability analysis is a method developed to evaluate the test, questionnaire, or scale features and reliability used in measurement (Kalayc1, 2010). In this study, test-retest reliability and internal consistency analysis were realized.

\subsubsection{Test-Retest reliability}

The scale, which was applied to 225 participants, was re-applied to 25 people selected among these participants at different times. In Table 8, the relationship between the scores gathered from the first and the second application was examined with the Pearson Correlation Coefficient in order to evaluate the invariance of the scale with 25 people over time. It was observed that there was a positive and highly significant linear relationship between the scale and sub-dimension scores $(\mathrm{p}<0.001)$. The high correlation between the first and second application scores indicates that the scale is reliable.

\begin{tabular}{ll}
\hline $\boldsymbol{R}$ & Relatiponship Level \\
(Correlation Coefficiency) & No relationship \\
\hline 0,00 & Low \\
$0,01-0,29$ & Average \\
$0,30-0,69$ & High \\
$0,70-0,99$ & Perfect Relationship \\
1,00 & \\
\hline
\end{tabular}

Table 8. Correlation Coefficients and Significance of Scale Sub-Dimensions between Test-Retest Scores

\begin{tabular}{lll}
\hline & R & p \\
\hline Total Points & 0,825 & $\mathbf{0 , 0 0 0}$ \\
Sub Dimension & & \\
F1 IK (Job Motivation) & 0,923 & $\mathbf{0 , 0 0 0}^{*}$ \\
F2 IT/Global (Safety of Service) & 0,821 & $\mathbf{0 , 0 0 0}$ \\
F3 Duty (Service Productivity and & 0,971 & $\mathbf{0 , 0 0 0}^{*}$ \\
Efficiency) & 0,934 & $\mathbf{0 , 0 0 0}$ \\
F4 Relationship (Behavioral) & &
\end{tabular}

$* p<0,001$

$r=$ Pearson Correlation Ciefficiency $p=$ Significance Level 


\subsubsection{Internal consistency coefficients}

The Cronbach Alpha internal consistency coefficients of the postmodernization scale and sub-dimensions of existing management processes were examined. Results are presented in Table 9.

Table 9. Internal Consistency Results

\begin{tabular}{llll}
\hline & $\begin{array}{c}\text { Article } \\
\text { Number Alpha }(\boldsymbol{\alpha})\end{array}$ & $\begin{array}{c}\text { Cronbach } \\
\text { Reliability Level }\end{array}$ \\
\hline $\begin{array}{l}\text { Postmodernization Scale of } \\
\text { Current Management Processes }\end{array}$ & 17 & 0,915 & Highly Reliable \\
Sub Dimensions & & & \\
F1 IK (Job Motivation) & 5 & 0,909 & Highly Reliable \\
F2 IT/Global (Safety of Service) & 4 & 0,829 & Highly Reliable \\
F3 Duty (Service Productivity and & 5 & 0,835 & Highly Reliable \\
$\begin{array}{l}\text { Efficiency) } \\
\text { F4 Relationship (Behavioral) }\end{array}$ & 3 & 0,643 & Quite Reliable \\
\hline $\begin{array}{l}0.00<\alpha<0.40 \text { Scale is not reliable } \\
0.40<\alpha<0.60 \text { Low relaiabliity }\end{array}$ & & & \\
$\begin{array}{l}0.60<\alpha<0.80 \text { Quite reliable } \\
0.80<\alpha<1.00 \text { Highly Reliable }\end{array}$ & & & \\
& & & \\
& & & \\
& & & \\
\hline
\end{tabular}

When Table 9 is examined; as a result of the reliability analysis applied, it was seen that the scale consisting of 17 Articles was highly reliable $(\alpha=0.915)$. F1 HR (Work motivation) sub-dimension $(\alpha=0.909)$, F2 IT/Global (Service Safety) subdimension $(\alpha=0.829)$ and F3 Task (Service Efficiency and Effectiveness) subdimension $(\alpha=0.835)$ were highly reliable; F4 Relationship (Behavioral) subdimension was found to be quite reliable $(\alpha=0.643)$.

\subsubsection{Correlation analysis results}

The postmodernization sub-dimension scores used in the study were examined with the assumptions of normality and it was determined that the assumption of normality was achieved in all scores. Therefore, Pearson Correlation Coefficient was used to examine the relationship between scores in the study. 


\begin{tabular}{lllll}
\hline $\boldsymbol{R}$ & Relatiopnship Level & Relationship Aspect \\
(Correlation Coefficient) & No relationship & & & \\
\hline 0,00 & Low & $r=\quad-\quad$ & negative \\
$0,01-0,29$ & Average & relationship & \\
$0,30-0,69$ & High & $r=\quad+$ & positive \\
$0,70-0,99$ & Perfect relationship & & relationship & \\
1,00 & & & \\
\hline
\end{tabular}

Table 10. Correlation Analysis Reuslts among Postmodernizationn Sub Dimension Scores

\begin{tabular}{|c|c|c|c|c|c|}
\hline $\begin{array}{l}\text { Postmodernization } \\
\text { Dimensions }\end{array}$ & Sub & $\begin{array}{l}\mathrm{F} 1 \\
\mathrm{IK}\end{array}$ & $\begin{array}{l}\text { F2 } \\
\text { IT/Global }\end{array}$ & $\begin{array}{l}\text { F3 } \\
\text { Görev }\end{array}$ & $\begin{array}{l}\mathrm{F} 4 \\
\text { İlişki }\end{array}$ \\
\hline $\begin{array}{l}\text { F1 IK } \\
\text { (Job motivation) }\end{array}$ & $\mathrm{r}$ & 1 & & & \\
\hline $\begin{array}{l}\text { F2 IT/Global } \\
\text { (Safety of Service) }\end{array}$ & $\mathrm{r}$ & $\begin{array}{l}0,531 \\
\mathbf{0 , 0 0 0}^{*}\end{array}$ & 1 & & \\
\hline $\begin{array}{l}\text { F3 Duty } \\
\text { (Service Productivity and } \\
\text { Efficiency) }\end{array}$ & $\mathrm{p}$ & $\begin{array}{l}0,572 \\
\mathbf{0 , 0 0 0 *}\end{array}$ & $\begin{array}{l}0,502 \\
\mathbf{0 , 0 0 0 *}\end{array}$ & 1 & \\
\hline $\begin{array}{l}\text { F4 Relationship } \\
\text { (Behavioral) }\end{array}$ & $\begin{array}{l}\mathrm{r} \\
\mathrm{p}\end{array}$ & $\begin{array}{l}0,662 \\
\mathbf{0 , 0 0 0}\end{array}$ & $\begin{array}{l}0,414 \\
\mathbf{0 , 0 0 0}^{*}\end{array}$ & $\begin{array}{l}0,517 \\
\mathbf{0 , 0 0 0}\end{array}$ & 1 \\
\hline $\begin{array}{l}\text { Average } \\
\text { Standard Deviation }\end{array}$ & & $\begin{array}{l}3,67 \\
1,209\end{array}$ & $\begin{array}{l}4,36 \\
0,801\end{array}$ & $\begin{array}{l}4,47 \\
0,705\end{array}$ & $\begin{array}{l}4,24 \\
0,794\end{array}$ \\
\hline
\end{tabular}

$*_{p}<0,001$

$r=$ Pearson Correlation Coefficency $p=$ Significance level

When Table 10 is examined, the HR score of those working in the air traffic control field is moderately positive $(r=0.531 ; \mathrm{p}<0.001)$, and the HR score is moderately positive $(\mathrm{r}=0.572 ; \mathrm{p}<0.001)$. $)$ and a moderately positive $(\mathrm{r}=0.662$; $\mathrm{p}<0.001)$ significant linear relationship between IK score and Relationship score, moderately positive $(\mathrm{r}=0.502 ; \mathrm{p}<0.001)$ between IT/Global score and Task score. There is a moderately positive $(r=0.414 ; \mathrm{p}<0.001)$ linear relationship between IT / Global score and Relationship score. There was also a moderately positive ( $r=0.517$; $\mathrm{p}<0.001)$ linear relationship between task score and Relationship score. 


\section{Structural equality model}

In this study, the model predicted for the Post-Modernization Scale of Existing Management Processes verified with 17 Articles and 4 sub-dimensions using AMOS software is presented in Figure 3.

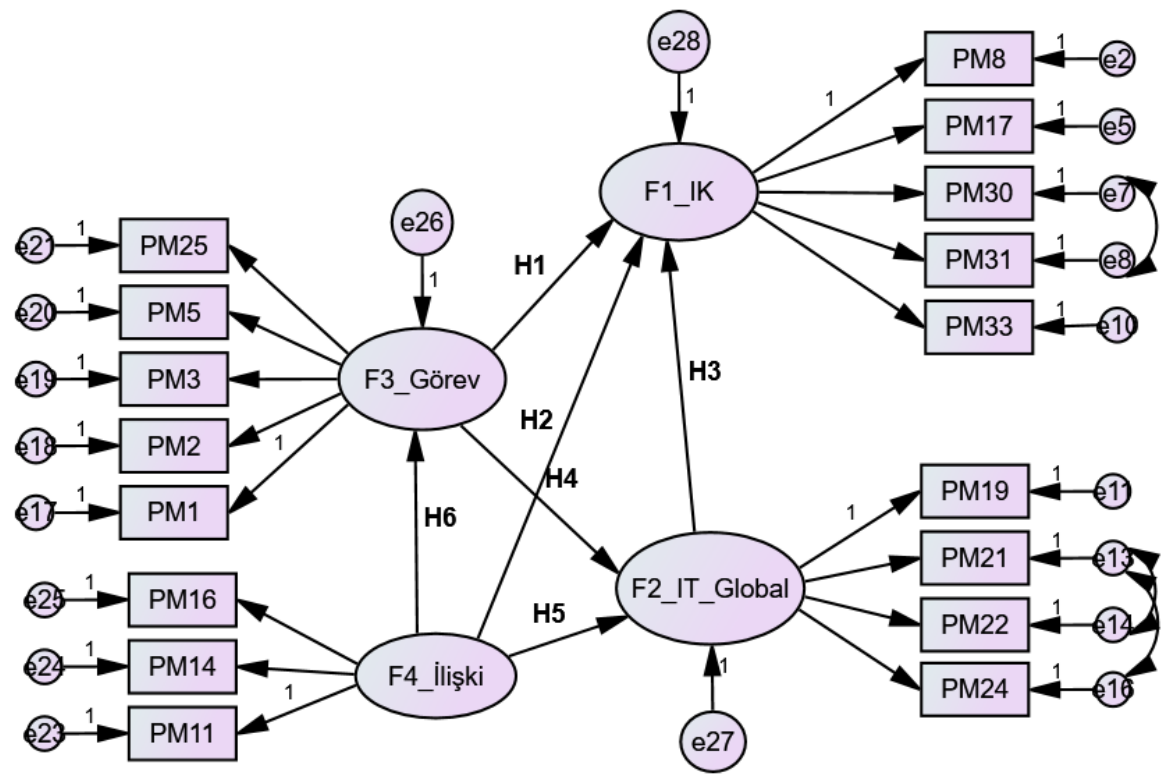

Figure 3. The projected structural model of the research

When Figure 3 is examined, it is seen that the model consists of 4 latent variables, and 3 of these latent variables are internal variables and 1 is exogenous. Internal variables; while IK is IT / Global and task, the external variable is the relationship. The main purpose of testing the model is to test the reasonal relationships between latent variables. Considering the hypotheses of the study, 6 paths were determined for 4 latent variables. At this stage, the structural equation model (SEM) was used.

Table 11. Adaptation index values of structural model

\begin{tabular}{|c|c|c|c|c|}
\hline & $\begin{array}{l}\text { Adaptation } \\
\text { index valus } \\
\text { of model }\end{array}$ & $\begin{array}{l}\text { Good } \\
\text { adaptation }\end{array}$ & $\begin{array}{l}\text { Acceptable } \\
\text { Adaptation }\end{array}$ & Adaptation \\
\hline$\chi^{2} / \mathrm{sd}$ & 2,357 & $\leq 3$ & $4-5$ & Good Adaptation \\
\hline GFI & 0,882 & $\geq 0,90$ & $(0,89-0,85)$ & $\begin{array}{l}\text { Acceptable } \\
\text { Adaptation }\end{array}$ \\
\hline AGFI & 0,855 & $\geq 0,90$ & $(0,89-0,85)$ & $\begin{array}{l}\text { Acceptable } \\
\text { Adaptation }\end{array}$ \\
\hline
\end{tabular}




\begin{tabular}{|c|c|c|c|c|}
\hline NFI & 0,902 & $\geq 0,95$ & $(0,94-0,90)$ & $\begin{array}{l}\text { Acceptable } \\
\text { Adaptation }\end{array}$ \\
\hline $\begin{array}{l}\text { NNFI } \\
(\mathrm{TLI})\end{array}$ & 0,919 & $\geq 0,95$ & $(0,94-0,90)$ & $\begin{array}{l}\text { Acceptable } \\
\text { Adaptation }\end{array}$ \\
\hline CFI & 0,934 & $\geq 0,95$ & $\geq 0,90$ & $\begin{array}{l}\text { Acceptable } \\
\text { Adaptation }\end{array}$ \\
\hline RMSEA & 0,078 & $\leq 0,05$ & $(0,06-0,08)$ & $\begin{array}{l}\text { Acceptable } \\
\text { Adaptation }\end{array}$ \\
\hline SRMR & 0,052 & $\leq 0,05$ & $(0,06-0,08)$ & Good Adaptation \\
\hline
\end{tabular}

In the study, the answer is sought: "Can the management processes be improved by increasing the efficiency, efficiency, safety and work motivation of the controllers in the postmodernization of the existing management processes used in the air traffic service?" The statements in the research hypotheses given within the scope of the problem are further elaborated and rearranged using the components in the above model as follows:

$H_{1}$ : In the postmodernization perception of current management processes of air traffic control employees, Mission (service efficiency and effectiveness) has a positive effect on HR (work motivation).

$\mathrm{H}_{2}$ : Relationship (behavioral) has a positive effect on HR (work motivation) in the perception of postmodernization of current management processes of those working in the field of air traffic control.

$H_{3}$ : It has a positive effect on IT / Global (safety of service), HR (work motivation) in the postmodernization perception of current management processes of air traffic control employees.

$H_{4}$ : Task (service efficiency and effectiveness) has a positive effect on IT / Global (safety of service) in the post-modernization perception of current management processes of those working in the field of air traffic control.

$H_{5}$ : Relation (behavioral) has a positive effect on IT/Global (safety of service) in the perception of post-modernization of current management processes of air traffic control workers.

$H_{6}$ : Relationship (behavioral) has a positive effect on Task (service efficiency and effectiveness) in the perception of postmodernization of current management processes of air traffic control workers. 




Figure 4. Structural equation model

Figure 4 shows the standardized regression coefficients of the roads on the one-way arrows of the structural equation model, which shows sufficient adaptation. In Table 12, the coefficients and significance of these roads are examined in detail.

Table 12. Path Coefficients and Significance Levels of the Structural Equation Model

\begin{tabular}{|c|c|c|c|c|c|c|c|c|}
\hline & & & & $\begin{array}{l}\text { Regression } \\
\text { Coeffcfiency } \\
(\beta)\end{array}$ & \begin{tabular}{|l|} 
Std. \\
Regression \\
Coeffcfiency
\end{tabular} & $\begin{array}{l}\text { Std. } \\
\text { error }\end{array}$ & $\mathbf{t}$ & $\mathbf{p}$ \\
\hline $\mathrm{H}_{1}$ & IK & $<--$ & Duty & $-0,273$ & $-0,155$ & 0,239 & $\begin{array}{l}- \\
1,141\end{array}$ & 0,254 \\
\hline $\mathrm{H}_{2}$ & IK & $<--$ & Relationship & 2,200 & 0,884 & 0,511 & 4,309 & $* * *$ \\
\hline $\mathrm{H}_{3}$ & IK & $<--$ & IT/Global & 0,539 & 0,211 & 0,266 & 2,026 & $0,043^{*}$ \\
\hline $\mathrm{H}_{4}$ & IT/Global & $<--$ & Duty & 0,268 & 0,388 & 0,093 & 2,884 & $0,004^{* * *}$ \\
\hline $\mathrm{H}_{5}$ & IT/Global & $<--$ & Relationship & 0,317 & 0,325 & 0,15 & 2,121 & $0,034^{*}$ \\
\hline $\mathrm{H}_{6}$ & Duty & <--- & Relationship & 1,004 & 0,710 & 0,177 & 5,69 & $* * *$ \\
\hline
\end{tabular}

$* p<0,05 * * p<0,01 * * * p<0,001$

When Table 12 is examined, it was seen that the $\mathrm{H} 1$ path coefficient in the structural model was not statistically significant ( $p>0.05$ ), while the H2, H3, H4, H5 and H6 path coefficients were found to be statistically significant $(\mathrm{p}<0.05)$. 


\section{Result and Suggestions}

"With a view to post modernizing the existing management processes utilized in the air transport sector, may the management processes be enhanced via increased efficiency, efficiacy, safety and the work motivation of the controllers?" In the first place, the measuring model of the post-modernisation scale of current management processes was built with the objective of testing the four hypotheses $(\mathrm{H} 1, \mathrm{H} 2, \mathrm{H} 3$, H4) established for solution of the problem. The measurement model developed consists of 17 validated Articles and four sub-dimensions. The findings and suggestions regarding the sub-dimensions are as follows:

F1 IK (Job Motivation): According to the PM8 statement, which is the strongest indicator of this sub-dimension, it is observed that correct and timely work is rewarded in the organization and this situation positively contributes to the work motivation of the employees. In order to increase the work motivation of the employees in the organization, efforts can be made to make the rewarding method more common and institutional. With increasing work motivation, employee productivity will increase and human-induced errors in the service provided will be minimized.

F2 IT/Global (Safety of the Serivce): According to the PM22 statement, which is the strongest indicator of this sub-dimension, it is observed that employees quickly adapt to computer operating system changes. This situation is expected to contribute positively to the safety of air traffic services, where almost all of the service processes are controlled by computer systems. Continuous updating of the computer communication systems used in the institution in parallel with the technological developments and providing the necessary training to the personnel will contribute positively to the service quality and human-induced errors will be minimized.

F3 Duty (Service Productivity and Efficiency): According to the PM2 statement, which is the strongest indicator of this sub-dimension, the internal job descriptions of the employees are clearly explained and this situation is expected to contribute positively to the efficiency and effectiveness of the service provided. Providing training that reinforce job descriptions and work processes to the employees in the organization at certain periods will also contribute positively to the safety of air traffic services.

F4 Relationship (Behavioral): According to the PM16 statement, which is the strongest indicator of this sub-dimension, employees' helping their colleagues in situations other than their job descriptions in the organization will contribute positively to solidarity within the organization and in parallel, increase the efficiency and effectiveness of the service provided. Organizing social activities that increase 
communication within the organization at certain times will contribute positively to the spirit of solidarity and teamwork culture within the organization.

According to the predicted structural model of the research created by using SEM in the study, 6 paths related to 4 latent variables were determined for the hypotheses developed. Based on the 6 paths determined in the structural model, the developed hypotheses were detailed and 6 hypotheses were obtained. The path coefficients of the $\mathrm{H} 2, \mathrm{H} 3, \mathrm{H} 4, \mathrm{H} 5$ and $\mathrm{H} 6$ hypotheses obtained were statistically significant; but it was determined that the path coefficient of the $\mathrm{H} 1$ hypothesis was not significant. According to this;

When the $\mathrm{H}_{1}$ hypothesis is examined; It has been determined that the task does not affect HR (Human Resources) in the post-modernization perception of the current management processes of those working in the field of air traffic control.

When the $\mathrm{H}_{2}$ hypothesis is examined; It has been determined that the relation affects HR positively and 1 unit increase of the Relationship increases the HR 2.2 times. $\mathrm{H} 2$ hypothesis is the hypothesis that contributes the most to the model according to the standardized regression coefficients. In order to increase the postmodernization perception of current management processes in the field of air traffic control, it is necessary to encourage cooperation within the organization, to pay attention to personal characteristics while distributing tasks, and to bring informal leadership to the fore.

When the $\mathrm{H}_{3}$ hypothesis is examined; It has been determined that IT/Global positively affects HR and 1 unit increase in IT/Global increases HR by 0.539 . In order to increase the post-modernization perception of the current management processes in the field of air traffic control, it is necessary to expand the use of information systems within the organization and to update the existing systems in parallel with technological developments.

When the $\mathrm{H}_{4}$ hypothesis is examined; It has been determined that the Task positively affects IT / Global and the 1 unit increase of the Task increases IT / Global by 0.268 . In order to increase the post-modernization perception of current management processes in the field of air traffic control in IT / Global specific terms, job descriptions and business processes should be clearly defined and explained to employees through periodic trainings.

When the $\mathrm{H}_{5}$ hypothesis is examined; It has been determined that the Relationship positively affects the IT / Global and that 1 unit increase of the Relationship increases IT / Global 0.317 times. In order to increase the postmodernization perception of the current management processes in the field of air traffic control in the IT/Global area, it is necessary to encourage intra-organizational 
cooperation, pay attention to personal characteristics when assigning tasks, and highlight in-organization informal leadership.

When the $\mathrm{H}_{6}$ hypothesis is examined; It has been determined that the Relationship positively affects the Task and that 1 unit increase of the Relationship increases the Task 1,004 times. According to the standardized regression coefficients, the H6 hypothesis is the second most contributing hypothesis to the model. In order to increase the post-modernization perception of current management processes in the field of air traffic control, it is necessary to encourage cooperation within the organization, to pay attention to personal characteristics while distributing the tasks, and to bring informal leadership to the fore.

As a result of this study, the perspectives of air traffic controllers on the postmodern management process are explained by relating them to their demographic characteristics. The results obtained will contribute to the improvement of management processes in the transition to a post-modern management approach in the field of air traffic control. In addition, measures that can be taken in order to maximize the postmodernization perceptions of the controllers within the current management processes have been determined.

All the findings achieved within the scope of the study raise awareness of the transition to postmodern air traffic control knowledge, and should help the literature on the postmodern model of management and to carry out science research on this issue.

\section{Disclosure statement}

No potential conflict of interest was reported by the authors. 


\section{References and notes:}

Button, K.Applied economics and understanding trends in air transportation policy. Transport Policy, 2019.78-85.

Büyüköztürk, Ş., Akgün, Ö. E., Kahveci, O. and Demirel, F. The validity and reliability study of the Turkish form of the motivation and learning strategies scale. Educational Sciences in Theory and Practice, 4(2), 2004.207-239.

Çokluk, Ö., Şekercioğlu, G. and Büyüköztürk, Ş. Multivariate statistics for social sciences: SPSS and LISREL applications. Ankara: Pegem Academy.2012

Demirel, D. "Public Administration from Modernism to Postmodernism", Firat University Journal of Social Sciences, Vol: 24, No: 2,2014. pp. 169-178.

Dragomir, C. Postmodern Maritime Human Resources Management-Amending the Maritime Labor Convention with Gender Requirements. PostmodernOpenings, 10(1), 2019.21-35.

Dursun, E. Effect of Work Stress and Burnout Perceptions of Aviation Sector Employees on Organizational Commitment, Journal of Contemporary Issues in Business and Government, 27, 3, 2021.412-417.

Dursun, E., Aydın, C., Çınar, E. ve Sertkaya, C. Estimation of commercial air line traffic with economic growth indicators, Journal of Contemporary Issues in Business and Government, 27(2), 2021.5683-5704.

Efendigil, T,. And Eminler, Ö. E. The Importance of Demand Forecasting in the Aviation Industry: A Forecasting Model on Passenger Demand. Operations Research in Agriculture and Food Value Chains and Industrial Engineering Special Issue. Volume:12,2016.

Eraslan H.Postmodernism Movement and Its Effects on Business Management, USOBED International Western Black Sea Journal of Social and Human Sciences, 2 (2):2018. 178193.

Higgoda, R., Madurapperuma, W. Dynamic Nexus between Air-transportation and Economic Growth: A Systematic Literature Review." Journal of Transportation Technologies, 9, 2019.56-170.

Kalayci, S. SPSS Applied Multivariate Statistical Techniques. Ankara: Asil.2010.

Kemp, L. J.Modern to postmodern management: developments in scientific management. Journal of Management History.2013.

Lacan, A.Think tank: Meaningful management in a postmodernsociety. Global Business and Organizational Excellence, 38(3), 2019, 6-10.

Metin S. Human Factors in Aviation Accidents in Recent Years. I. National Aviation Medicine Congress. Congress Abstract Book: Eskişehir, 2014, 22-24.

Ozdemir, I. Reflections of postmodern thought on the education system in Turkey. National Education, 204 (Fall): 2014.18-41.

Ozturk, I. The Reflection of Postmodernism on Human Behaviors in the Organization. International Journal of Economics and Innovation, 5(1), 2019.91-100.

Tahtalioglu, H.. The reflection of postmodernism on the Turkish public bureaucratic system. Aksaray University Faculty of Economics and Administrative Sciences Journal, 10(1), 2018.19-28.

Ulutaş M.. Postmodern Organizational Structures. Literaturk Academy: Istanbul.2018.

Yasar, H., Akgun, O. E. Expectations of Ninth Grade Students about the Content and Method of Information and Communication Technology Course. Journal of National Education, 45(211), 97-111. Publication Distribution, 2016. 403.

Zerenler, D., Özilhan, Ö., and Akgöbek, Ö. Postmodern Orientation of Marketing and Transformation in Business Structures on the Axis of Globalization. Journal of Selcuk University Vocational School of Social Sciences, 12 (1-2), 2014. 391-408. 


\title{
XÜLASכ
}

\section{Hava Nəqliyyatına Nəzarət Xidmətlərində Postmodernizmə keçidin Nəzarətçilər perspektivindən araşdırılması}

\author{
Cankut AYDIN \\ Cənubi Universitetin İdarəetma Biznes va Hüquq İnstitutu, \\ Rostov-Don,Russiya
}

Ertan ÇINAR

Eskişehir Texniki Universiteti, Türkiya

\begin{abstract}
$\mathrm{Bu}$ məqalənin məqsədi ənənəvi idarəetmə texnikalarından ibarət postmodern hava hərəkətinə nəzarət xidmətlərinə keçidləri nəzarətçilər tərəfindən araşdıraraq, idarəetmə proseslərini yaxşılaşdırmaqdır. Tədqiqat nümunəsi kimi Türkiyədə aktiv lisenziyalı "Hava Nəqliyyat Nəzarətçisi" olaraq çalışan 225 nəfərdən ibarətdir. Tədqiqat zamanı hava nəqliyyat nəzarətçilərinin post-modern idarəetmə prosesi ilə bağlı perspektivləri demoqrafik xüsusiyyətləri ilə əlaqələndirilir.
\end{abstract}

Tədqiqatın nəticələri hava hərəkətinə nəzarət sahəsində post-modern idarəetmə yanaşmasına keçid zamanı insan resursları idarəetmə proseslərinin yaxşılaşdırılmasına kömək edir. Bundan əlavə, mövcud idarəetmə prosesləri daxilində nəzarətçilərin modernləşmədən sonrakı təsəvvürlərini maksimum dərəcədə artırmaq üçün alınacaq tədbirlər müəyyən edilmişdir. Tədqiqat çərçivəsində əldə edilən bütün nəticələrin post-modern idarəetmə modeli ədəbiyyatına və elmi tədqiqatlarına töhfə verəcəyi, eyni zamanda hava nəqliyyatına nəzarət sahəsində post-modern idarəetmə yanaşmasına keçid üçün məlumatlılı̆ı̆ı artacağı gözlənilir. Bu daha sonra həyata keçiriləcəkdir.

Açar sözlor: "Hava Nəqliyyat Nəzarətçisi", insan resursları, postmodern, nəzarət xidmətləri, keçid 
РЕЗЮМЕ

\title{
Исследование перехода к постмодернизму в службах управления воздушным движением с точки зрения диспетчеров
}

\author{
Джанкут АЙДИН \\ Южный Институт управления, бизнеса и права, \\ Ростов-на-Дону, Россия \\ Эртан ЧИНАР \\ Технический университет Эскишехира, Туричии
}

\begin{abstract}
В этом исследовании цель состоит в том, чтобы улучшить процессы управления, изучая с точки зрения диспетчеров переход от традиционных методов управления к постмодернистским службам управления воздушным движением. Выборка исследования состоит из 225 человек, работающих в Турции в качестве действующих лицензированных «авиадиспетчеров». В исследовании точки зрения авиадиспетчеров на постмодернистский процесс управления были объяснены в связи с их демографическими характеристиками. Результаты исследования способствуют совершенствованию процессов управления человеческими ресурсами при переходе к постмодернистскому подходу к управлению в области управления воздушным движением. Кроме того, были определены меры, которые могут быть предприняты для максимизации постмодернизационного восприятия контроллеров в рамках текущих процессов управления. Ожидается, что все результаты, полученные в рамках исследования, повысят осведомленность о переходе к постмодернистскому подходу к управлению в области управления воздушным движением, а также внесут вклад в литературу и научные исследования, посвященные постмодернистской модели управления будут сделаны по этой теме с этого момента.
\end{abstract}

Ключевые слова: «Авиадиспетчер», человеческий ресурс, постмодерн, диспетчерские службы, переходный период.

ELM VO INNOVATIV TEXNOLOGIYALAR JURNALI 